\title{
Are Bilateral Real Exchange Rates Stationary? Revisiting the Evidence from India
}

\author{
Soumya Kanti Ghosh1, Hiranya K. Nath ${ }^{2,3 *}$ \\ ${ }^{1}$ State Bank of India, Mumbai, India \\ ${ }^{2}$ Department of Humanities \& Social Sciences, Indian Institute of Technology, Guwahati, India \\ ${ }^{3}$ Department of Economics \& International Business, Sam Houston State University, Huntsville, USA \\ Email: *eco_hkn@shsu.edu
}

How to cite this paper: Ghosh, S.K. and Nath, H.K. (2016) Are Bilateral Real Exchange Rates Stationary? Revisiting the Evidence from India. Theoretical Economics Letters, 6, 1196-1204.

http://dx.doi.org/10.4236/tel.2016.65113

Received: September 21, 2016

Accepted: October 18, 2016

Published: October 21, 2016

Copyright $\odot 2016$ by authors and Scientific Research Publishing Inc. This work is licensed under the Creative Commons Attribution International License (CC BY 4.0).

http://creativecommons.org/licenses/by/4.0/ (c) (i) Open Access

\begin{abstract}
Appreciation or overvaluation of exchange rates in times of capital flows and its impact on exports or even imports is a matter of policy debate. Against such a background, this paper examines empirical evidence of stationarity in the data on India's bilateral real exchange rates with 16 of its major trading partner countries over a period of 5 decades (from 1960 to 2012). The results from the Lagrange multiplier (LM) unit root test with two structural breaks provide evidence of stationarity only for 9 countries. This is in contrast with the overwhelming evidence of stationarity in earlier studies. The rapid growth of international trade and capital flows particularly prior to the 2008 financial crisis and a concomitant shift in exchange rate regime may have significantly affected the behavior of India's real exchange rate vis-à-vis some of the countries in our sample. This has implications for the Reserve Bank of India (RBI) to sustain its intervention pace on a continuous basis given the fear of rupee being overvalued. The associated liquidity injection will have important implications for the conduct of India's monetary policy.
\end{abstract}

\section{Keywords}

India, Bilateral Real Exchange Rate, Lagrange Multiplier(LM) Unit Root Test, Structural Break

\section{Introduction}

There was a major shift in India's economic policy paradigm in 1991. It conducted market-oriented reforms, opened up the economy to international trade and foreign investment, and moved to a market-determined exchange rate regime. These developments have an important bearing on the behavior of India's real exchange rate vis-à-vis 
its major trading partner countries. With the growing importance of trade and foreign investment for India's economic growth and development, it is critical to know whether disturbances to real exchange rates have a permanent or a transitory effect. Thus, this paper examines the stationarity of India's bilateral real exchange rate with 16 of its major trading partner countries from 1960 to 2012, extending the works of Narayan [1] and Hegwood and Nath [2].

Bilateral nominal exchange rate is the value of one currency expressed in terms of another currency. When this exchange rate is adjusted for the differences in prices between the two countries, we have bilateral real exchange rates. The purchasing power parity (PPP) hypothesis has been the major theoretical framework for examining the dynamic behavior of real exchange rate. This hypothesis, based on the law of one price, suggests that, "once converted to a common currency, national price levels should be equal" [3]. The empirical testing of this hypothesis is tantamount to testing for stationarity of the real exchange rate. This is important for at least three reasons. First, PPP is regarded as a long-run equilibrium or an arbitrage condition for goods and assets markets in most models of exchange rate determination. Second, real exchange rate movement is important for inter-temporal smoothing of traded goods consumption [4] and for cross-country redistribution and transfer of wealth [5]. Third, evidence of meanreversion or a lack of it is useful for identifying the shocks that characterize real exchange rate dynamics. For example, evidence of mean-reversion indicates that nominal disturbances have only transitory impact on real exchange rate while a lack of such evidence implies that permanent real shocks are behind the real exchange rate movements.

Numerous empirical studies on the PPP hypothesis have been conducted and published over last several decades. The results have been mixed: while some studies find evidence to support the hypothesis, others do not. Rogoff [3] and Taylor and Taylor [6] provide extensive survey of this literature. Note that, in addition to the studies cited above, there are other studies [7] [9] that have examined exchange rate behavior in India.

Using Lagrange multiplier (LM) unit root test with two breaks, Narayan [1] finds evidence of stationarity in annual bilateral real exchange rate data covering the period 1960-2000 for 15 out of 16 countries. Hegwood and Nath [2] extend the sample period to 2010 and use panel data test procedures to show that the evidence of stationarity is stronger with structural breaks. These results provide empirical support for the PPP hypothesis and imply that shocks to real exchange rates are transitory for almost all countries in the sample. However, the sample period in Narayan [1] covers less than a decade since India's transition to a market-oriented system. Furthermore, since Hegwood and Nath [2] consider common structural breaks, the potential heterogeneity in the bilateral exchange rate behavior that may depend on country-specific events is not adequately captured in their study. Although the results presented in that study highlight the importance of structural changes that took place in India, they do not shed any light on country specific events with long-run implications for real exchange dynamics. 
There have been significant increases in India's trade with the rest of the world and in foreign investment from abroad since 2000. For example, the GDP share of trade increased from about 21\% in FY2000 to about 37\% in FY2015. Net inflows of foreign direct investment (FDI) as a share of GDP rose from $0.75 \%$ in FY2000 to about 3.5\% in 2008 and then dropped to about $1.5 \%$ in FY2015. Furthermore, inflows of foreign institutional (portfolio) investment (FII) as a share of GDP rose from $0.01 \%$ in FY2000 to about $0.33 \%$ in 2008 and further to about $1.5 \%$ in FY2015. The growth of trade and capital flows is expected to have affected the behavior of India's real exchange rate in recent years. Furthermore, there have been important differences in the evolution of international economic and financial relationship with different countries around the world. Consequently, the relative shares of different countries in trade investment flows have changed over the years. For example, in the mid-1990s, the US accounted for the largest share of imports into India. Currently, China holds that distinction. During the same period, the US has been the largest destination for India's exports although the share has declined from about $20 \%$ in 1996-97 to about 13\% in 2013-14. Against this backdrop, in this short paper, we reexamine the evidence of stationarity in India's real exchange rate with the 16 countries in Narayan [1] and Hegwood and Nath [2] by extending the dataset until 2012.

The rest of the paper is organized as follows. Section 2 briefly discusses data and methodology. In Section 3, we present our main empirical results. A discussion of the results and their implications is included in Section 4. The last section concludes.

\section{Data and Methodology}

\subsection{Data}

We obtain annual data on nominal exchange rates and consumer price indices (CPIs) for India and 16 countries from 1960 to 2012 from the World Development Indicators (WDI) database, compiled and maintained by the World Bank ${ }^{1}$. The base year for CPI is 2005. The countries are: Australia, Canada, France, Germany, Hong Kong, Italy, Japan, Korea, Malaysia, New Zealand, Pakistan, Philippines, Sri Lanka, Thailand, the United Kingdom, and the United States. The nominal exchange rates are in terms of the number of domestic currency per unit of US dollar (USD). We divide a country's nominal exchange rate by India's nominal exchange rate to obtain the bilateral nominal exchange rate in terms of that country's currency per unit of Indian Rupee (INR) ${ }^{2}$. We then multiply this by relative price between India and the country under consideration (India's CPI divided by the other country's CPI) to calculate the corresponding bilateral

${ }^{1}$ CPI data for Germany from 1960 to 1990, for Hong Kong from 1960 to 1980, for the U.K. from 1960 to 1987, and for South Korea from 1960 to 1965 are not available from this data source. We obtain historical data on CPI inflation for those countries from inflation.eu-Worldwide Inflation Data website

(http://www.inflation.eu/inflation-rates/cpi-inflation.aspx) and use them to calculate CPI for the missing years. Furthermore, Euro was introduced in France, Germany, and Italy in 1999. The nominal exchange rates for these three countries for subsequent years are adjusted using the euro conversion rates for Eurozone member countries announced on December 31, 1998 (see European Central Bank 1998) [8].

${ }^{2}$ Although data on bilateral nominal exchange rates of INR are available for a few countries in recent years, they are not available for all the years in our sample. 
real exchange rate ${ }^{3}$.

The choice of these countries is primarily dictated by the availability of data ${ }^{4}$ These 16 countries together accounted for about $29 \%$ of India's total trade in 2011-2012. Further, 9 out of these 16 countries are among the top 25 trading partners of India ${ }^{5}$. The US alone accounts for more than $11 \%$ of India's exports, $5 \%$ of imports, and more than $7 \%$ of total trade.

\subsection{Methodology}

Introducing structural breaks in unit root tests has been a way of resolving the so-called PPP puzzle, the inability to find evidence of stationarity of real exchange rate. It also makes intuitive sense to consider such breaks particularly when the sample period has reasonable length. Since there have been changes in the policy paradigms and exchange rate regimes in India, it is but natural to expect structural breaks in its real exchange rate series. Therefore, like Narayan [1], we conduct the Minimum Lagrange Multiplier (LM) unit root test with two structural breaks as suggested by Lee and Strazicich [10]. Consider the following data generating process (DGP):

$$
r_{t}=\delta^{\prime} Z_{t}+e_{t}, \quad e_{t}=\beta e_{t-1}+\varepsilon_{t}
$$

where $r_{t}$ is the bilateral real exchange rate; $Z_{t}$ is a vector of exogenous variables and $\varepsilon_{t}$ is iid $N\left(0, \sigma^{2}\right)$. We allow for breaks in level as well as in trend and, therefore,

$$
Z_{t}=\left[1, t, D_{1 t}, D_{2 t}, D T_{1 t}, D T_{2 t}\right]^{\prime}
$$

where $D_{j t}=1$ for $t \geq T_{B j}+1$ and 0 otherwise; and $D T_{j t}=t-T_{B j}$ for $t \geq T_{B j}+1, j=1$, 2 , and 0 otherwise. $T_{B S}$ S denote the break dates. In order to estimate the LM unit root test statistic, Lee and Strazicich (2003) use the following regression:

$$
\Delta r_{t}=\delta^{\prime} \Delta Z_{t}+\phi \tilde{S}_{t-1}+u_{t}
$$

where $\tilde{S}_{t}=r_{t}-\tilde{\psi}_{x}-Z_{t} \tilde{\delta}, t=2, \cdots, T ; \tilde{\delta}$ are coefficients in the regression of $\Delta r_{t}$ on $\Delta Z_{\dot{p}} \quad \tilde{\psi}_{x}$ is given by $r_{1}-Z_{1} \tilde{\delta}$; and $r_{1}$ and $Z_{1}$ are the first observations of $r_{t}$ and $Z_{t}$ respectively. The unit root null hypothesis is that $\phi=0$ and the LM test statistic is given by: $\tilde{\tau}=t$-statistic for testing the above null. The structural break dates $\left(T_{B j}\right)$ are endogenously determined through a grid search such that the LM test is minimum:

$$
L M_{t}=\inf _{\lambda} \tilde{\tau}(\lambda) \text { where } \lambda=\frac{T B}{T}
$$

The grid search is conducted over the trimming region $(0.15 T, 0.85 T)$ where $T$ is the sample size. Critical values are provided by Lee and Strazicich [10]. Note that we use RATS software for applying this methodology to our dataset.

\section{Empirical Results}

Table 1 presents the results for the LM unit root test with two structural breaks. The

${ }^{3}$ For details, see Hegwood and Nath [2].

${ }^{4}$ This set of countries was previously used by Narayan [1].

${ }^{5}$ Note that 7 out of 25 top trading partners of India, not included in our sample, are oil rich countries of the Middle East and Africa and oil is the major import items from these countries. 
Table 1. Lee-Strazicich two-break unit test results.

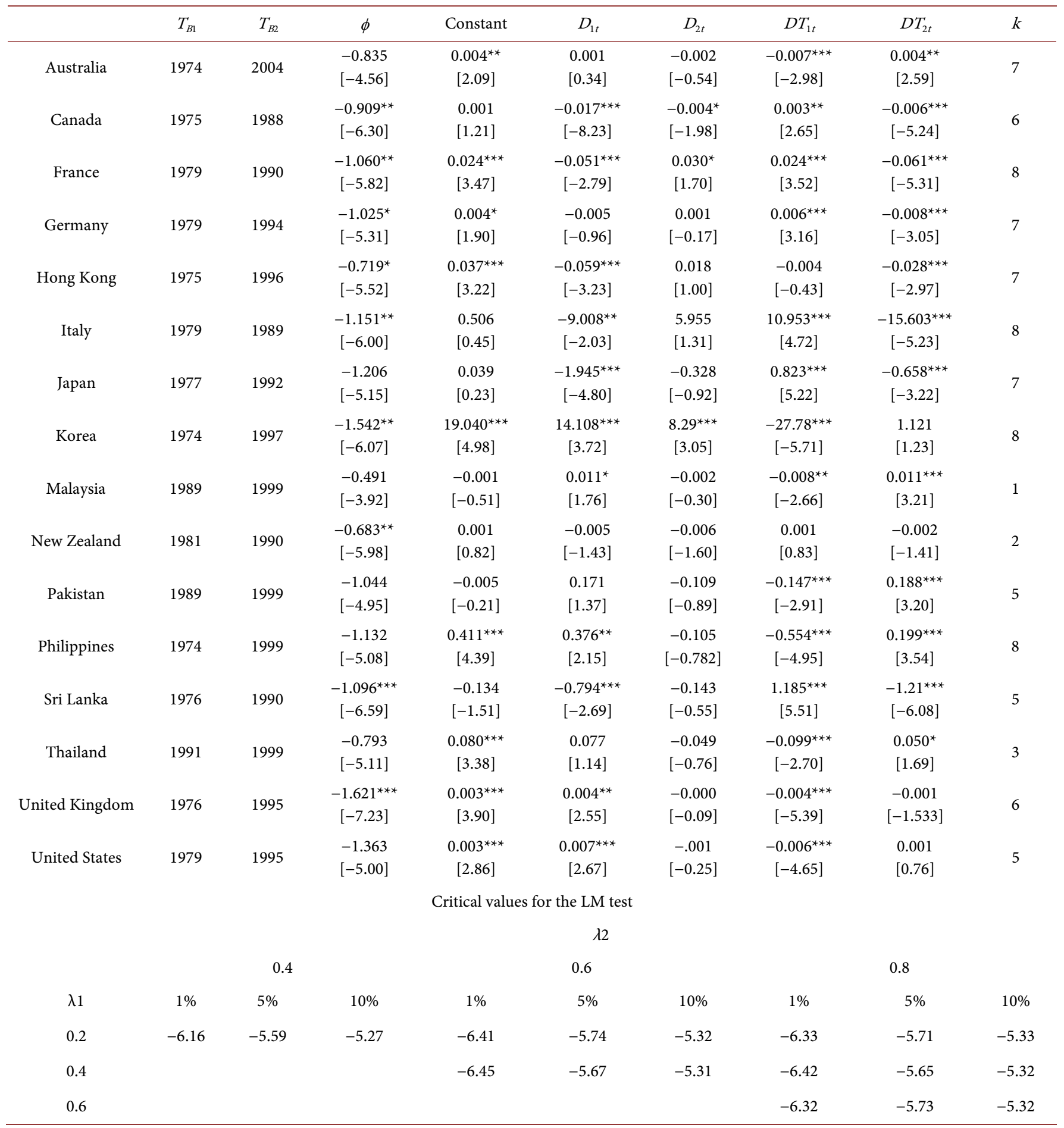

Notes: ${ }^{* *},{ }^{* *},{ }^{*}$ denote statistical significance at the $1 \%, 5 \%$, and $10 \%$ levels, respectively. The critical values are taken from Lee and Strazicich [10].

test is able to reject the unit root null at least at the $10 \%$ level for nine countries. Note that Narayan [1] was able to reject the unit root null for 15 out of 16 countries. The countries for which we do not find evidence of stationarity include advanced countries 
like Australia, Japan, and the United States, and emerging market economies (EMEs) of Malaysia, Pakistan, Philippines, and Thailand $d^{6}$ The only country for which Narayan [1] finds no evidence of stationarity was South Korea ${ }^{7}$. However, with the extended dataset, we are able to reject the unit root null for this country.

As for the break dates, the first structural break occurred between the oil price shocks of 1973 and 1979 for 12 countries. For Malaysia, Pakistan and Thailand, the first break occurred close to India's BOP crisis in 1991. The second break occurred after India's economic reform for 11 countries. For Canada, France, Italy, New Zealand, and Sri Lanka, we find the second break just before the crisis of 1991. However, without further investigation, we cannot suggest that these particular events had anything to do with the structural breaks. The fact that there are wide variations in the break dates seems to suggest a significant role for country-specific factors, study of which is beyond the scope of this short note. Note that Hegwood and Nath [2] find the first common break in 1971 and the second break in 1988.

\section{Discussion}

As it is clear from our discussion above, both trade and capital inflows have been growing faster than GDP during the last decade or so. The behavior of India's bilateral real exchange rates has been affected by the evolution of trade, capital flows, and movements of relative prices in specific countries. Without a formal analysis, we briefly discuss some of these developments below.

India experienced large inflows of capital well in excess of its current financing needs (net of capital account balance minus current account balance) over the years except in 2009 (\$-20.5 billion) and 2012 (\$-10.4 billion), when foreign investors were skeptical about global economic recovery. This resulted in high domestic credit and monetary expansion, boom in capital markets and other asset prices, and in general excess domestic demand leading to macroeconomic and financial instability in the domestic economy.

Figure 1 depicts excess capital flows and the movements in USD-INR nominal exchange rates during 2000-16. In the early 2000s, as the US monetary policy shifted towards a low interest rate regime, the search for yield among foreign investors intensified and capital flows to India rose manifold to an annual average of $\$ 46.4$ billion during 2003-13 reaching a peak of $\$ 90.8$ billion in 2008. While FDI flows witnessed a steady increase over the period, FII and other private flows (short term trade credit and banking capital) exhibited substantial volatility. Note that FDI flows largely reflect the pull factors whereas FII and bank flows reflect both the push and the pull factors. Over

${ }^{6}$ Like Narayan [1], we also conduct Augmented Dickey-Fuller test with no structural break and LM test with one structural break. There are less number of rejections of the null hypothesis and the results are consistent with those of Narayan [1]. However, we do not report them in this short paper.

${ }^{7}$ For appropriate comparison, we also conduct the LM test with two breaks for the sample period 1969-2000 as in Narayan [1]. We are able to find evidence of stationarity for 14 out of 16 countries. The unit root null cannot be rejected for Malaysia and Pakistan. Besides, although the results for other countries are qualitatively similar to those in Narayan [1], the parameter estimates are different. We suspect that there may have been some differences in the data due to data revision as they were collected almost 10 years apart. 


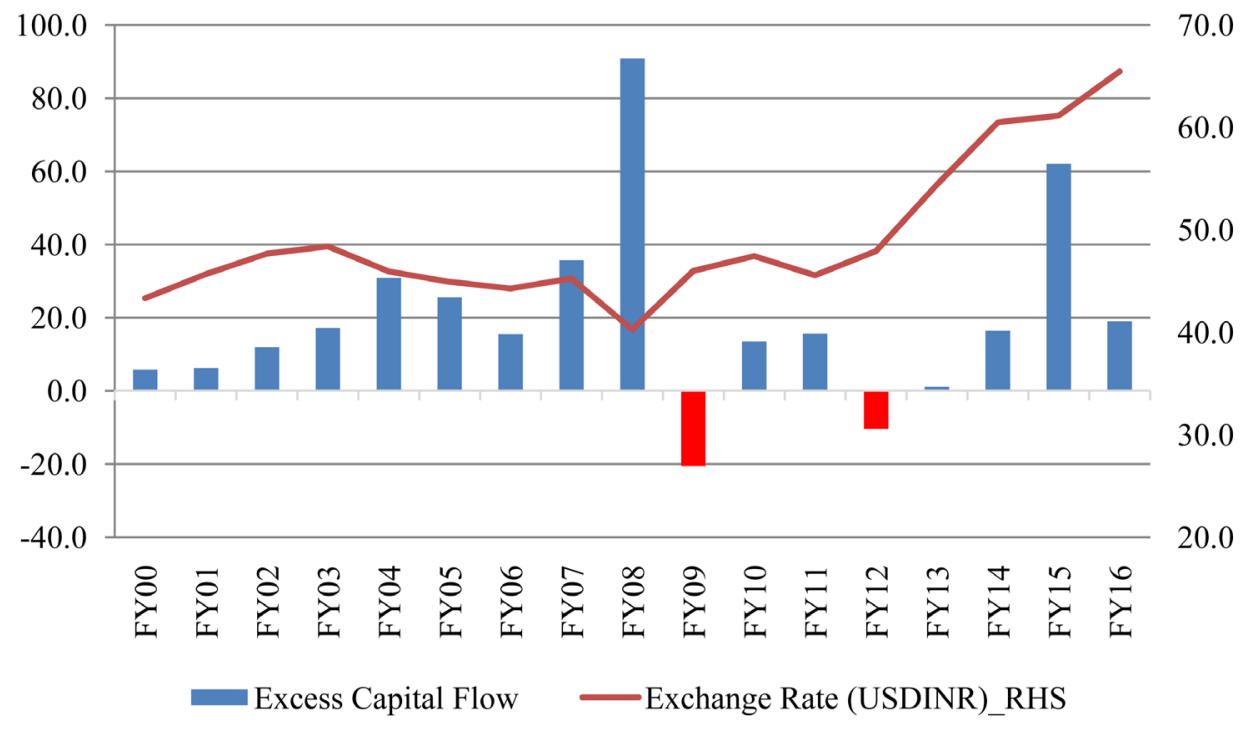

Figure 1. Excess capital flows over financing needs into India (\$ billion) and USD-INR nominal exchange rates during 2000-16. Notes: (a) Excess capital flows is estimated as net of capital account and current account balance. (b) The successive years refer to financial years that runs from April to March of next year (2014 thus refers to April 2013 till Match 2014). Source: Reserve Bank of India.

all, capital account transactions grew much faster (average growth of 53\%) relative to current account transactions (19.0\%).

The accommodative monetary policy in advanced economies, primarily in the US, after the financial crisis was also mirrored in the strong base money expansion during 2008-12 with an average growth rate of $12.4 \%$, much higher than the expansion at the rate of $2.4 \%$ during the previous five years: 2003-07. As a consequence, inflation accelerated. These developments are intricately related to the exchange rate movements that are likely to vary across countries depending on the nature of their relationships with India in terms of capital and current account transactions and movements in relative prices $^{8}$.

In FY2015, excess capital flows (net of capital account balance minus current account balance) were $\$ 62$ billion (in FY16 they declined to $\$ 19$ billion). This provides multiple challenges for the Reserve Bank of India (RBI). First, RBI would need to sustain its intervention pace on a continuous basis, given the constant fears of rupee getting overvalued (that is substantiated by the evidence of non-stationarity and structural breaks) ${ }^{9}$. Such real appreciation has likely resulted in loss of competitiveness of our exports in FY2015. Second, such intervention will have attendant liquidity injection which will have several ramifications for RBI in terms of a faster than anticipated reserve money growth and hence money supply.

${ }^{8}$ The sudden stops in capital flows during 2013-14 did have an impact on the nominal exchange rate: it declined by $32 \%$ in 2014 over 2011. Furthermore, the CPI inflation rate has averaged 9.7\% (Jan'2012 till March 2014), implying that these factors may have continued to influence the movements in real exchange rate even beyond 2012.

${ }^{9}$ In FY2015, RBI accumulated an estimated $\$ 50$ billion through spot market. 


\section{Conclusion}

This paper examines empirical evidence of stationarity in the data on India's bilateral real exchange rate with 16 of its major trading partner countries from 1960 to 2012, extending the study by Narayan [1] and Hegwood and Nath [2]. The results from the Lagrange multiplier (LM) unit root test with two structural breaks provide evidence of stationarity only for 9 countries. This is in contrast with the overwhelming evidence of stationarity in the previous studies. The rapid growth of international trade and capital flows, and a shift in exchange rate regime may have significantly affected the behavior of India's real exchange ratevis-à-vis some of the countries in our sample. This is the most important contribution of this relatively short paper. However, this needs further research. Furthermore, the evolving dynamics of India's real exchange rate will not be captured by a formal analysis until after sufficiently long time series data are available. With this caveat, our empirical evidence and "somewhat informal" discussion of current trends in this short article can be interpreted as suggestive of the most plausible path for the real exchange rate evolution and consistent future policy paradigm in India.

\section{Acknowledgements}

The authors would like to express their gratitude for the editorial comments that have been useful in revising the paper. The opinions expressed in this paper are those of the authors and do not necessarily reflect those of the State Bank of India or other members of its staff.

\section{References}

[1] Narayan, P.K. (2006) Are Bilateral Real Exchange Rates Stationary? Evidence from Lagrange Multiplier Unit Root Tests for India. Applied Economics, 38, 63-70. http://dx.doi.org/10.1080/00036840500365983

[2] Hegwood, N.D. and Nath, H.K. (2014) Real Exchange Rate Dynamics: Evidence from India. Economic Analysis and Policy, 44, 396-404. http://dx.doi.org/10.1016/j.eap.2014.09.004

[3] Rogoff, K. (1996) The Purchasing Power Parity Puzzle. Journal of Economic Literature, 14, 647-668.

[4] Rogoff, K. (1992) Traded Goods Consumption Smoothing and the Random Walk Behavior of the Exchange Rate. Bank of Japan Monetary and Economic Studies, 10, 1-29.

[5] Obstfeld, M. and Rogoff, K. (1995) The International Approach to the Current Account. In: Grossman, G.M. and Rogoff, K., Eds., Handbook of International Economics, Vol. 3, North Holland, New York, 1737-1799.

[6] Taylor, A.M. and Taylor, M.P. (2004) The Purchasing Power Parity Debate. Journal of Economic Perspectives, 18, 135-158. http://dx.doi.org/10.1257/0895330042632744

[7] Baghestani, H. (1997) Purchasing Power Parity in the Presence of Foreign Exchange Black Markets: The Case of India. Applied Economics, 29. http://dx.doi.org/10.1080/00036849700000005

[8] European Central Bank (1998) Determination of the Euro Conversion Rates. Press Release. http://www.ecb.europa.eu/press/pr/date/1998/html/pr981231_2.en.html 
[9] Kohli, R. (2002) Real Exchange Rate Stationarity in Managed Floats: Evidence from India. ICRIER Working Paper 93.

[10] Lee, J. and Strazicich, M.C. (2003) Minimum Lagrange Multiplier Unit Root Test with Two Structural Breaks. Review of Economics and Statistics, 85, 1082-1089.

http://dx.doi.org/10.1162/003465303772815961

Submit or recommend next manuscript to SCIRP and we will provide best service for you:

Accepting pre-submission inquiries through Email, Facebook, LinkedIn, Twitter, etc. A wide selection of journals (inclusive of 9 subjects, more than 200 journals)

Providing 24-hour high-quality service

User-friendly online submission system

Fair and swift peer-review system

Efficient typesetting and proofreading procedure

Display of the result of downloads and visits, as well as the number of cited articles

Maximum dissemination of your research work

Submit your manuscript at: http://papersubmission.scirp.org/

Or contact tel@scirp.org 